\title{
Synergistic Effect of Biosynthesized Silver Nanoparticles and Natural Phenolic Compounds against Drug-Resistant Fish Pathogens and Their Cytotoxicity: An In Vitro Study
}

\author{
Ehab Essawy ${ }^{1,2,3, *}$, Mohamed S. Abdelfattah ${ }^{2,4}{ }^{\mathbb{D}}$, Mansour El-Matbouli ${ }^{1}$ and Mona Saleh ${ }^{1}$ \\ 1 Clinical Division of Fish Medicine, University of Veterinary Medicine, 1210 Vienna, Austria; \\ mansour.El-Matbouli@vetmeduni.ac.at (M.E.-M.); mona.saleh@vetmeduni.ac.at (M.S.) \\ 2 Department of Chemistry, Faculty of Science, Helwan University, Cairo 11795, Egypt; \\ mabdelfattah@science.helwan.edu.eg \\ 3 Helwan Nanotechnology Center, Helwan University, Cairo 11795, Egypt \\ 4 Marine Natural Products Unit, Faculty of Science, Helwan University, Cairo 11795, Egypt \\ * Correspondence: ehab.essawy@vetmeduni.ac.at; Tel.: +43-1-250774736; Fax: +43-1-250775192
}

\section{check for} updates

Citation: Essawy, E.; Abdelfattah, M.S.; El-Matbouli, M.; Saleh, M. Synergistic Effect of Biosynthesized Silver Nanoparticles and Natural Phenolic Compounds against Drug-Resistant Fish Pathogens and Their Cytotoxicity: An In Vitro Study. Mar. Drugs 2021, 19, 22. https:// doi.org/10.3390/md19010022

Received: 19 November 2020

Accepted: 6 January 2021

Published: 8 January 2021

Publisher's Note: MDPI stays neutral with regard to jurisdictional clai$\mathrm{ms}$ in published maps and institutional affiliations.

Copyright: (C) 2021 by the authors. Licensee MDPI, Basel, Switzerland. This article is an open access article distributed under the terms and conditions of the Creative Commons Attribution (CC BY) license (https:// creativecommons.org/licenses/by/ $4.0 /)$.
Abstract: Fish pathogens causing disease outbreaks represent a major threat to aquaculture industry and food security. The aim of the presented study is to develop safe and effective bioactive agents against two bacterial isolates: Aeromonas hydrophila and Pseudomonas fluorescens. We employed a broth microdilution method to investigate the antibacterial effect of biosynthesized silver nanoparticles (AgNPs); rutin, a natural flavonoid extracted from Ruta graveneoles; and heliomycin, a secondary metabolite produced by marine actinomycetes AB5, as monotherapeutic agents. Moreover, AgNPs in combination with rutin $(\mathrm{AgNP}+\mathrm{R})$ and heliomycin $(\mathrm{AgNPs}+\mathrm{H})$ were examined for their synergistic effect. The cytotoxic effect of individual bioactive compounds and in combination with AgNPs was investigated on epithelioma papulosum cyprini (EPC) fish cell lines. Individual treatment of AgNPs, rutin, and heliomycin exhibited a dose-dependent antimicrobial activity against $A$. hydrophila and $P$. fluorescens. Rutin minimum inhibitory concentration (MIC) showed the lowest cytotoxicity when tested on EPC cell lines, while heliomycin MIC was highly cytotoxic. Combined subtherapeutic doses of AgNPs $+\mathrm{R}$ and AgNPs $+\mathrm{H}$ displayed additive and synergistic effects against $A$. hydrophila and $P$. fluorescens, respectively, with improved results and relative safety profile. The study findings demonstrate that a combination of AgNPs and natural bioactive compounds may represent novel therapeutics fighting fish pathogens potentially affecting the fish farming industry.

Keywords: AgNPs; rutin; heliomycin; synergistic effect; fish pathogens; EPC

\section{Introduction}

Sustainment of healthy farmed fish is a significant economic and ecological capital in both developed and developing countries [1]. Fish pathogens causing disease outbreaks are considered a major threat, alarming the aquaculture industry and food security [2] especially after the emergence of several antibiotic-resistant bacterial strains [3]. Aeromonas hydrophila is a fish pathogen that causes hemorrhagic septicemia syndrome [4], leading to increased mortality in aquaculture [5]. The conventional antibiotic treatment against $A$. $h y$ drophila is limited because of its ability to form a biofilm with diversified exopolysaccharide (EPS) [6]. Psedomonas fluorescens is a Gram-negative bacterium existing in diverse ecological niches. It infects a variety of farmed fish, including grass carp (Ctenopharyngodon idella), tilapia (Oreochromis spp.), trout, and Japanese flounder (Paralichthys olivaceus) [5]. Fish infected with $P$. fluorescens develop "red skin" disease that can lead to heavy mortality [7]. Hence, investigations for new therapeutics against $A$. hydrophila and P. fluroscens are required to control the emergence of high virulent strains due to the misuse of antibiotics [8].

Recently, modern treatment modalities for fish diseases have been developed using bionanotechnology [9]. Metal nanoparticles (NPs) such as gold NPs, silver NPs (AgNPs), 
and zinc oxide NPs showed antimicrobial activities against several fish pathogens, enabling an alternative approach for controlling disease outbreaks [10,11]. In our previous study, AgNPs exhibited antibacterial and antifungal activities including Aeromonas salmonicida and Aphanomyces invadans, respectively [12]. Moreover, we recommended chitosan nanoparticles to control invasive bacterial species [13]. However, safety concerns have been raised over the usage of AgNPs due to their potential side effects [14]. Oral administration of chemically synthesized AgNPs in Labeu rohita lead to bioaccumulation in gills, liver, and muscles. Moreover, a marked alteration in hematological parameters and pathological damage in tested tissues were observed [15].

Therefore, new bioactive compounds for safe and effective antimicrobial therapy should be considered. Biosynthesized AgNPs are supposed to have a better safety level [16]. Additionally, plant-derived flavonoids, a large group of naturally occurring phenylchromones found in fruits and vegetables, have diverse biological activities [17]. Rutin $\left(3,3^{\prime}, 4^{\prime}, 5\right.$, 7 pentahydroxyflavone-3-hamnoglucoside) is a flavonoid glycosidic compound found mainly in lemons, oranges, berries, limes, and grapes. Rutin exhibits a variety of biological and pharmacological activities, including antioxidant, antidiabetic, immunomodulatory, anti-inflammatory, and neuroprotective effects [18,19]. Heliomycin is a secondary metabolite released from marine actinomyctes. It is an aromatic polyketide in structure [20] and exhibits antibacterial, antiviral, and anticancer activities [21,22]. Heliomycin inhibits RNA polymerase [23] that leads to apoptosis [22] and inhibition of RNA and protein synthesis. Additionally, it acts as a histone deacetylase inhibitor [24]. Therefore, we postulated that combined treatment of natural products and biosynthesized AgNPs might offer a balanced solution between efficacy and safety. In the present study, we aimed to develop novel, safe, and effective therapeutic compounds against the two bacterial strains affecting the aquaculture industry. To achieve this goal, we tested biosynthesized AgNPs, rutin, and heliomycin, and combinations of AgNPs and rutin (AgNPs + R) and AgNPs and heliomycin (AgNPs + $\mathrm{H}$ ) against $A$. hydrophila and P. fluorescens (Figure 1). A cytotoxicity study was performed to test the compounds on epithelioma papulosum cyprinid (EPC) fish cell lines to evaluate their safety. We believe that it is the first study on the synergistic inhibitory effects of biosynthesized AgNPs, phytogenic compounds, and secondary metabolites on the pathogens affecting aquaculture, namely $A$. hydrophila and P. fluorescens. Both Gram-negative strains were selected as they are potentially pathogenic for fish and humans, more cross resistant to popular antibiotics, and more abundant in aquaculture fish and water [25].

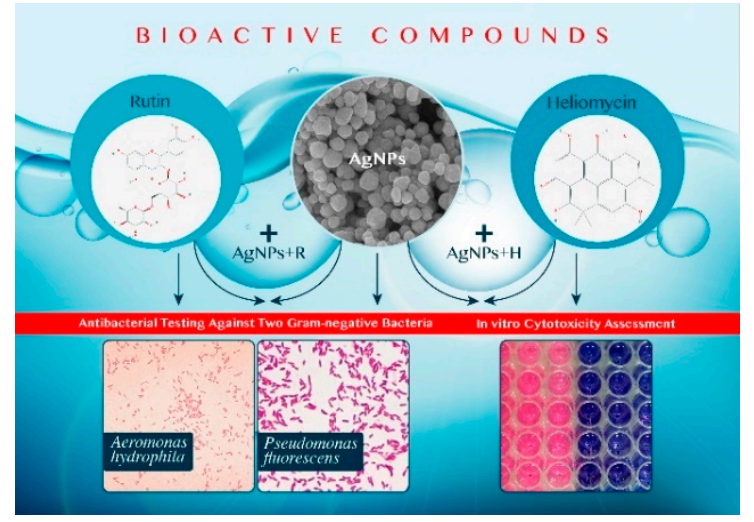

Figure 1. Graphical representation for testing the synergistic/additive effects of silver nanoparticles (AgNPs) to rutin and heliomycin against Aeromonas hydrophila and Pseudomonas fluorescens; and cytotoxcity testing.

\section{Results}

\subsection{Characterization of the Biosynthesized AgNPs (Particle Size and Zeta Potential)}

The mean size and size distribution profile of the biosynthesized AgNPs are shown in Figure 2. The particle size distribution shows two intensity peaks at $12.1 \mathrm{~nm}$ and $73.7 \mathrm{~nm}$, 
with an average diameter of $56.1 \mathrm{~nm}$ and a polydispersity index (PDI) of 0.36 , which indicates good homogeneity of the AgNPs (Figure 2a). The surface potential of $-33.8 \mathrm{mv}$ (Figure 2b) indicates a good stability against coalescence.
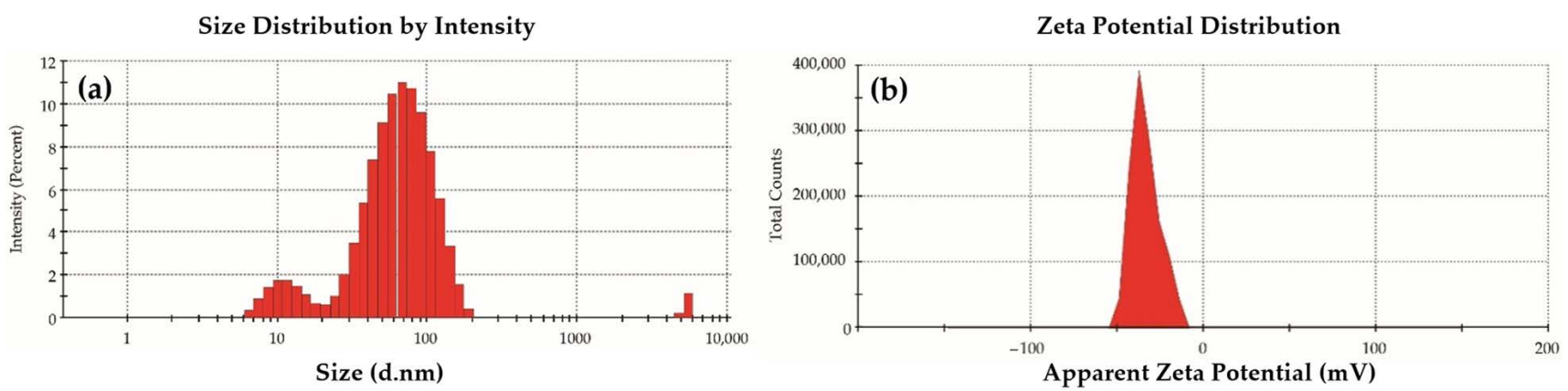

Figure 2. Characterization of biosynthesized AgNPs. (a) Particle size distribution with intensity peaks at $12.1 \mathrm{~nm}$ and $73.7 \mathrm{~nm}$, average size of $56.1 \mathrm{~nm}$, and polydispersity index (PDI) of 0.36 , which indicates good homogeneity of the AgNPs.

(b) Zeta potential distribution with maximum charge of -33.8 . All data are expressed as means $\pm \operatorname{SD}(n=3)$.

\subsection{Antibacterial Effects of Bioactive Compounds}

\subsubsection{Minimum Inhibitory Concentration (MIC)}

A considerable dose-dependent antibacterial effect of rutin, heliomycin, and AgNPs against both bacterial isolates $A$. hydrophila and $P$. fluorescens was observed by the broth microdilution method, which is evident from the explored MIC values (Table 1). The lowest MIC value was recorded for AgNPs $(2 \mu \mathrm{g} / \mathrm{mL})$ against $A$. hydrophila, followed by rutin against $P$. fluorescens, and the highest MIC value was recorded for heliomycin at $2048 \mu \mathrm{g} / \mathrm{mL}$ against A. hydrophila.

Table 1. Identified minimum inhibitory concentration (MIC) and minimum bactericidal concentration (MBC) values of rutin (R), heliomycin (H), and silver nanoparticles (AgNPs) against A. hydrophila and P. fluorescens.

\begin{tabular}{cccc}
\hline Compound & Strain & MIC $(\mu \mathrm{g} / \mathrm{mL})$ & MBC $(\mu \mathrm{g} / \mathrm{mL})$ \\
\hline \multirow{2}{*}{ Rutin } & A. hydrophila & 1024 & 2048 \\
\cline { 2 - 4 } & P. fluorescens & 1024 & 2048 \\
\hline \multirow{2}{*}{ Heliomycin } & A. hydrophila & 2048 & $(-)$ \\
\cline { 2 - 4 } & P. fluorescens & 1024 & $(-)$ \\
\hline \multirow{2}{*}{ AgNPs } & A. hydrophila & 2 & 20 \\
\cline { 2 - 4 } & P. fluorescens & 4 & 20 \\
\hline
\end{tabular}

(-): MIC and MBC values that did not reach for all doses examined in this study.

\subsubsection{Determining Minimum Bactericidal Concentration (MBC)}

The lowest treatment concentration that prevented $99.9 \%$ of the bacterial growth on agar plates was recorded at $20 \mu \mathrm{g} / \mathrm{mL}$ AgNPs against A. hydrophila (Figure 3). The bactericidal effect of rutin was observed for both tested strains and inhibited their colonial growth (Table 1). The lowest MBC value was recorded against $P$. fluorescence at $20 \mu \mathrm{g} / \mathrm{mL}$ of AgNPs, indicating high susceptibility, while the highest MBC value was recorded at $2048 \mu \mathrm{g} / \mathrm{mL}$ of rutin against $A$. hydrophila. Heliomycin exhibited bacteriostatic activity against both strains but could not inhibit their colonial growth at the tested concentrations (Table 1). 


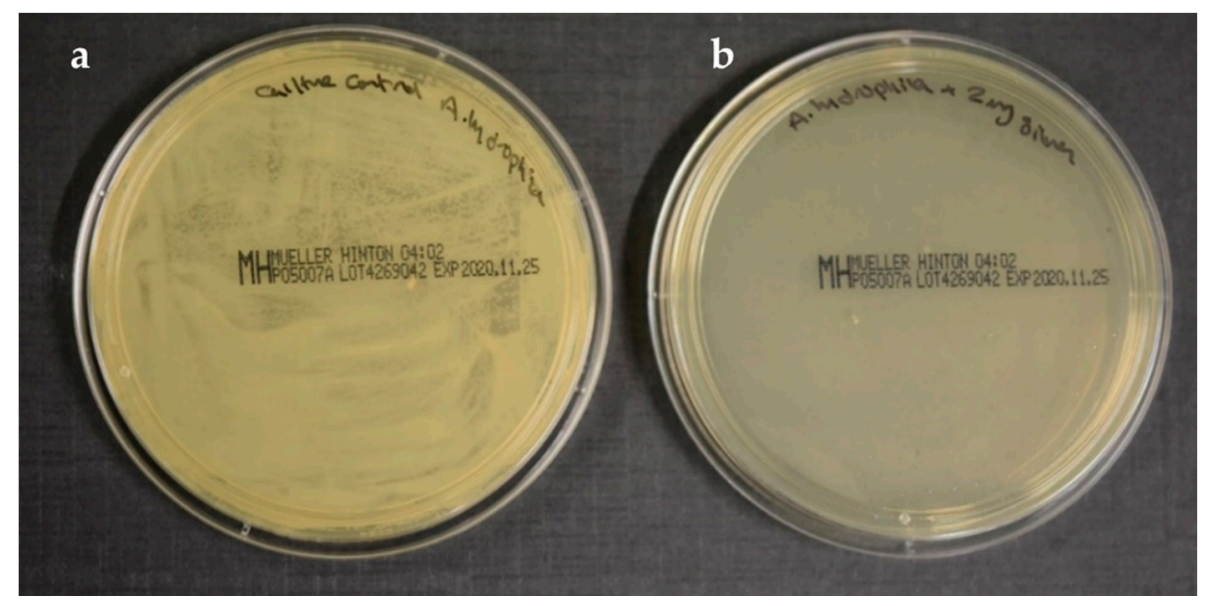

Figure 3. The bactericidal effect of silver nanoparticles against A. hydrophila. (a) Bacterial culture of A. hydrophila. (b) Treated plate with AgNPs $(2 \mu \mathrm{g} / \mathrm{mL})$.

\subsubsection{Synergy Studies}

A serial dilution of rutin and heliomycin sub-MIC-0.5 MIC, $0.25 \mathrm{MIC}, 0.125 \mathrm{MIC}$, and 0.062 MIC—was selected for combinations with AgNPs sub-MIC of $1 \mu \mathrm{g} / \mathrm{mL}$ (Tables 2-4).

Table 2. Selected combinations of sub-MIC doses for synergy study.

\begin{tabular}{|c|c|c|c|}
\hline Compound & Strain & Selected Sub-MIC $(\mu \mathrm{g} / \mathrm{mL})$ & $\begin{array}{l}\text { Concentrations Used in Synergy } \\
\text { Study }(\mu \mathrm{g} / \mathrm{mL})\end{array}$ \\
\hline Rutin & $\begin{array}{l}\text {-A hydrophila. } \\
\text {-P. fluorescens }\end{array}$ & $\begin{array}{l}\text { R512, } \\
\text { R256, } \\
\text { R128, } \\
\text { R64 }\end{array}$ & $\begin{array}{l}\text { R } 512(\mu \mathrm{g} / \mathrm{mL})+\text { AgNPs } 1 \mu \mathrm{g} / \mathrm{mL} \\
\text { R } 256(\mu \mathrm{g} / \mathrm{mL})+\text { AgNPs } 1 \mu \mathrm{g} / \mathrm{mL} \\
\text { R } 128(\mu \mathrm{g} / \mathrm{mL})+\text { AgNPs } 1 \mu \mathrm{g} / \mathrm{mL} \\
\text { R } 64(\mu \mathrm{g} / \mathrm{mL})+\text { AgNPs } 1 \mu \mathrm{g} / \mathrm{mL}\end{array}$ \\
\hline Heliomycin & $\begin{array}{l}\text {-A. hydrophila } \\
\text {-P. fluorescens }\end{array}$ & $\begin{array}{l}\text { H512, } \\
\text { H256, } \\
\text { H128, } \\
\text { H64 }\end{array}$ & \multirow{2}{*}{$\begin{array}{c}\text { H } 512(\mu \mathrm{g} / \mathrm{mL})+\text { AgNPs } 1 \mu \mathrm{g} / \mathrm{mL} \\
\text { H } 256(\mu \mathrm{g} / \mathrm{mL})+\text { AgNPs } 1 \mu \mathrm{g} / \mathrm{mL} \\
\text { H } 128(\mu \mathrm{g} / \mathrm{mL})+\text { AgNPs } 1 \mu \mathrm{g} / \mathrm{mL} \\
\text { H } 64(\mu \mathrm{g} / \mathrm{mL})+\text { AgNPs } 1 \mu \mathrm{g} / \mathrm{mL}\end{array}$} \\
\hline AgNPs & $\begin{array}{l}\text {-A. hydrophila } \\
\text {-P. fluorescens }\end{array}$ & 1 & \\
\hline
\end{tabular}

Table 3. Results of interaction study between rutin (R) and silver nanoparticles (AgNPs).

\begin{tabular}{|c|c|c|c|c|}
\hline Strain & $\begin{array}{c}\mathrm{MIC}_{\text {AgNPs }} / \mathrm{MIC}_{\mathrm{R}} \\
\text { (Alone, } \mu \mathrm{g} / \mathrm{mL} \text { ) }\end{array}$ & $\begin{array}{c}\mathrm{MIC}_{\text {AgNPs } / \mathrm{MIC}_{\mathrm{R}} \text { (in }} \\
\text { Combination, } \\
\mu \mathrm{g} / \mathrm{mL})\end{array}$ & FICI & Effect \\
\hline A. hydrophila & $2 / 1024$ & $1 / 64$ & 0.562 & $\mathrm{~A}$ \\
\hline P. fluorescens & $4 / 1024$ & $1 / 64$ & 0.3125 & $\mathrm{~S}$ \\
\hline
\end{tabular}

FICI, fractional inhibitory concentration index; S, synergy; A, additivity. The FICI interpretation: $\leq 0.5$, synergy; $0.5-4.0$, indifference; and $>4.0$, antagonism.

Table 4. Results of interaction study between heliomycin $(\mathrm{H})+$ silver nanoparticles (AgNPs).

\begin{tabular}{|c|c|c|c|c|}
\hline Strain & $\begin{array}{c}\mathrm{MIC}_{\text {AgNPs }} / \mathrm{MIC}_{\mathrm{H}} \\
\text { (Alone, } \mu \mathrm{g} / \mathrm{mL} \text { ) }\end{array}$ & $\begin{array}{l}\mathrm{MIC}_{\text {AgNPs }} / \mathrm{MIC}_{\mathrm{H}} \text { (in } \\
\text { Combination, } \mu \mathrm{g} / \mathrm{mL})\end{array}$ & FICI & \\
\hline A. hydrophila & $2 / 2048$ & $1 / 64$ & 0.531 & A \\
\hline P. fluorescens & $4 / 1024$ & $1 / 64$ & 0.3125 & $\mathrm{~S}$ \\
\hline
\end{tabular}

FICI, fractional inhibitory concentration index; S, synergy; A, additivity. The FIC indices were interpreted as follows: $\leq 0.5$, synergy; $0.5-4.0$, indifference; and $>4.0$, antagonism. 


\subsubsection{Synergistic Effect Using the Disc Diffusion Method}

A wider zone of inhibition was observed (Figure 4) with the combination of 0.5 MIC of AgNPs $(2 \mu \mathrm{g} / \mathrm{mL})$ with $0.5 \mathrm{MIC}$ of rutin and heliomycin $(512 \mu \mathrm{g} / \mathrm{mL})$, which indicates a synergistic effect of the combinations (Table 5).

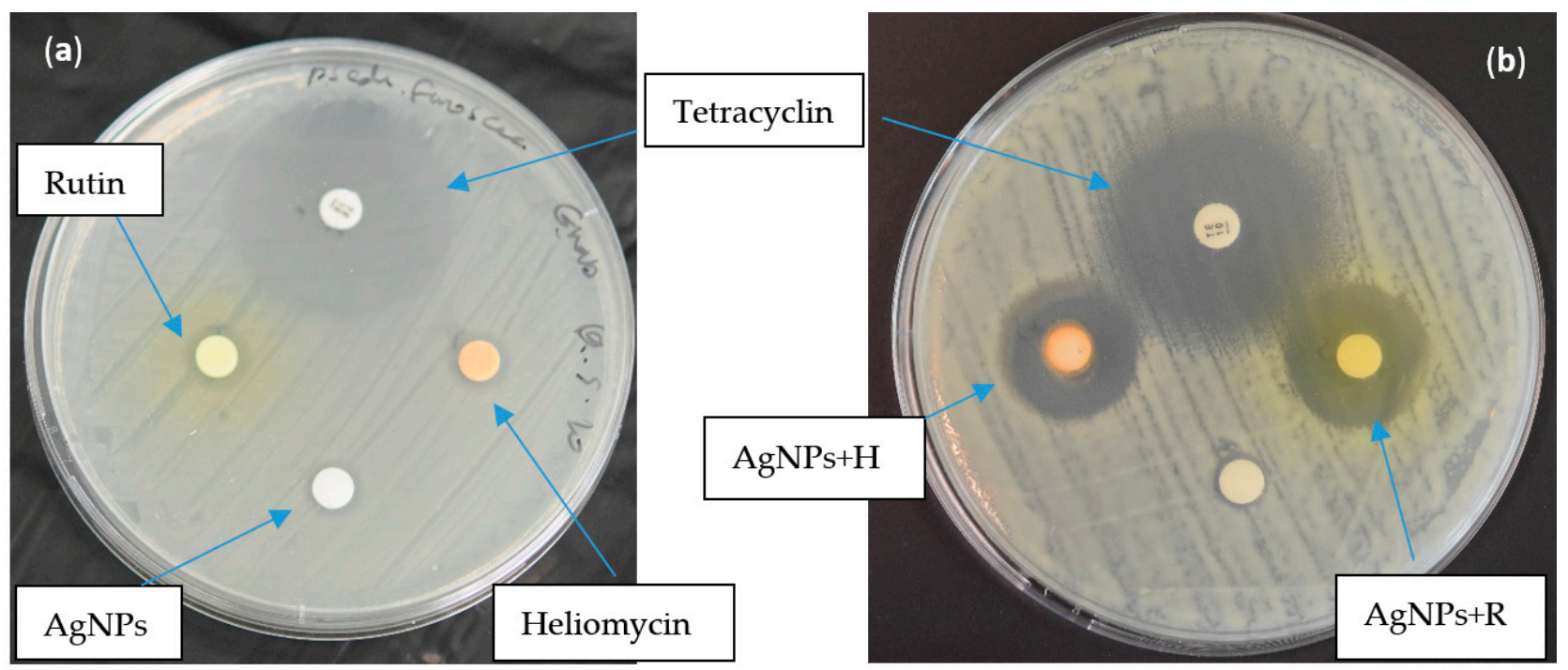

Figure 4. Disc diffusion assay results for the antibacterial effect of tested bioactive compounds against $P$. fluorescens. (a) Zone of inhibition for individual compounds: rutin R $(512 \mu \mathrm{g} / \mathrm{mL})$, heliomycin R $(512 \mu \mathrm{g} / \mathrm{mL}), \operatorname{AgNPs}(2 \mu \mathrm{g} / \mathrm{mL})$, and tetracycline $(10 \mu \mathrm{g})$ as positive control. (b) Widening of inhibition zone (arrow) for the combination of AgNPs $+\mathrm{R}$ and AgNPs $+\mathrm{H}$ at the same concentrations.

Table 5. Zone of inhibition of compounds against P. fluorescens.

\begin{tabular}{clc}
\hline Bioactive Compound & Strain & $\begin{array}{c}\text { Zone of } \\
\text { Inhibition }\end{array}$ \\
\hline Rutin $(512 \mu \mathrm{g} / \mathrm{mL})$ & P. fluorescens & $9 \pm 0.2 \mathrm{~mm}^{\mathrm{a}}$ \\
\hline Heliomycin $(512 \mu \mathrm{g} / \mathrm{mL})$ & P. fluorescens & $8 \pm 0.3 \mathrm{~mm}^{\mathrm{a}}$ \\
\hline AgNPs $(2 \mu \mathrm{g} / \mathrm{mL})$ & P. fluorescens & $8 \pm 0.1 \mathrm{~mm}^{\mathrm{a}}$ \\
\hline AgNPs $(2 \mu \mathrm{g} / \mathrm{mL})+$ Rutin $(512 \mu \mathrm{g} / \mathrm{mL})$ & P. fluorescens & $23 \pm 0.8 \mathrm{~mm}^{\mathrm{b}}$ \\
\hline AgNPs $(2 \mu \mathrm{g} / \mathrm{mL})+$ Heliomycin $(512 \mu \mathrm{g} / \mathrm{mL})$ & P. fluorescens & $22 \pm 0.5 \mathrm{~mm}^{\mathrm{b}}$ \\
\hline Tetracycline (Positive Control) & P. fluorescens & $30 \pm 0.1 \mathrm{~mm}^{\mathrm{c}}$ \\
\hline
\end{tabular}

The values are expressed as means \pm SD. Different letters ( $a, b$ and $c)$ in the same column mean that they are significantly different $(p \leq 0.05)$.

\subsubsection{Effect of Bioactive Compounds on Bacterial Growth}

The bacterial growth inhibition of bioactive compounds alone and in combination with silver nanoparticles was confirmed by the broth microdilution method after overnight incubation at $22{ }^{\circ} \mathrm{C}$ by lower absorbance capacities at $600 \mathrm{~nm}$ using an absorbance microplate reader, Tecan Sunrise (Männdorf, Switzerland). The results show a dose-dependent antibacterial activity of the tested compounds and their bactericidal or bacteriostatic effect against A. hydrophila and P. fluorescens, as shown in Figures 5-7. 


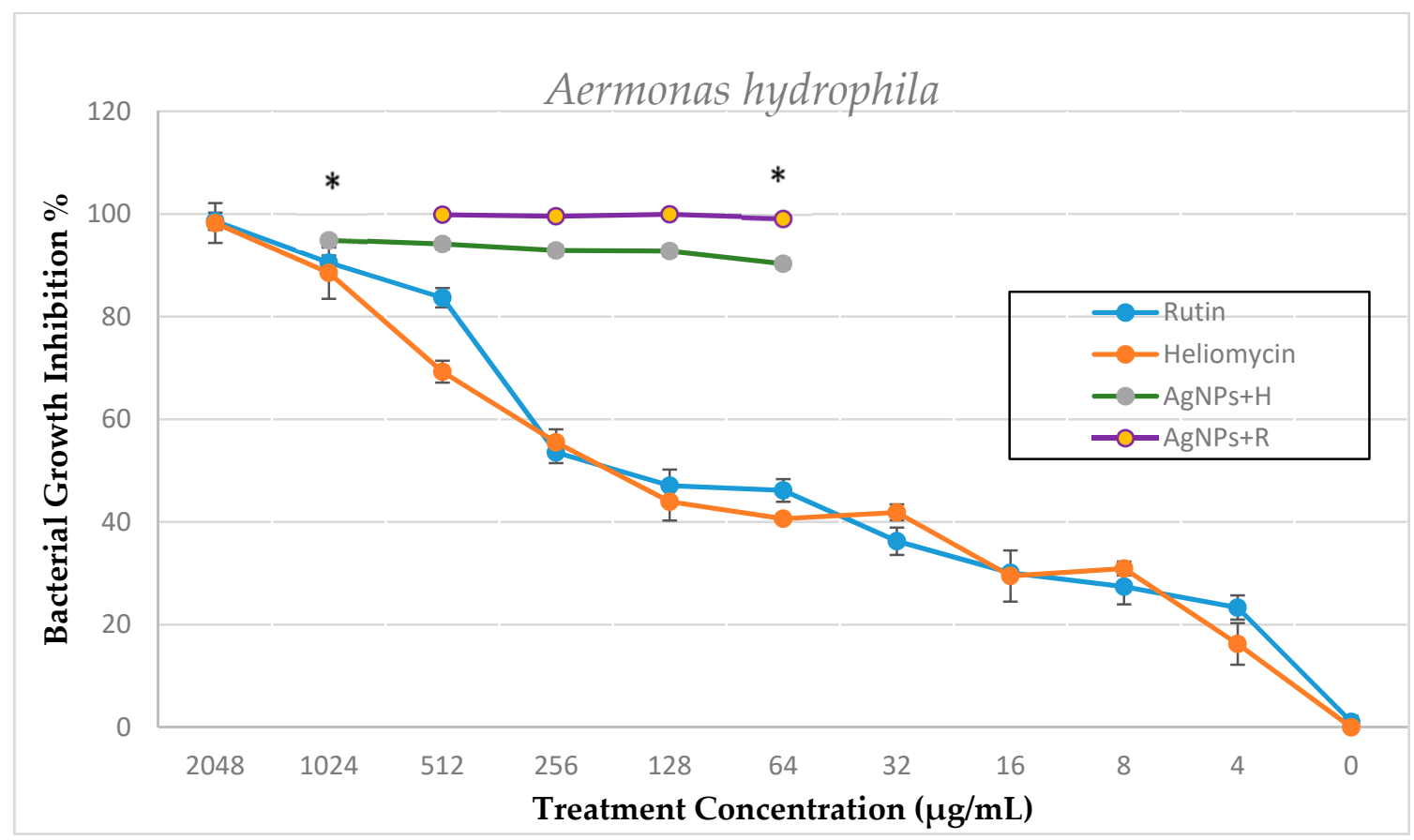

Figure 5. Percent inhibition of $A$. hydrophila growth when tested against a serial dilution of rutin and heliomycin $(2048 \mu \mathrm{g} / \mathrm{mL}$ to $0 \mu \mathrm{g} / \mathrm{mL}$ ) and sub-MIC combinations of AgNPs + rutin (R) and AgNPs+ heliomycin (H). All data are expressed as means $\pm \mathrm{SD}(n=3)$. Error bars represent the standard deviation from average values. ${ }^{*}$ Statistical significance from control $(p<0.05)$.

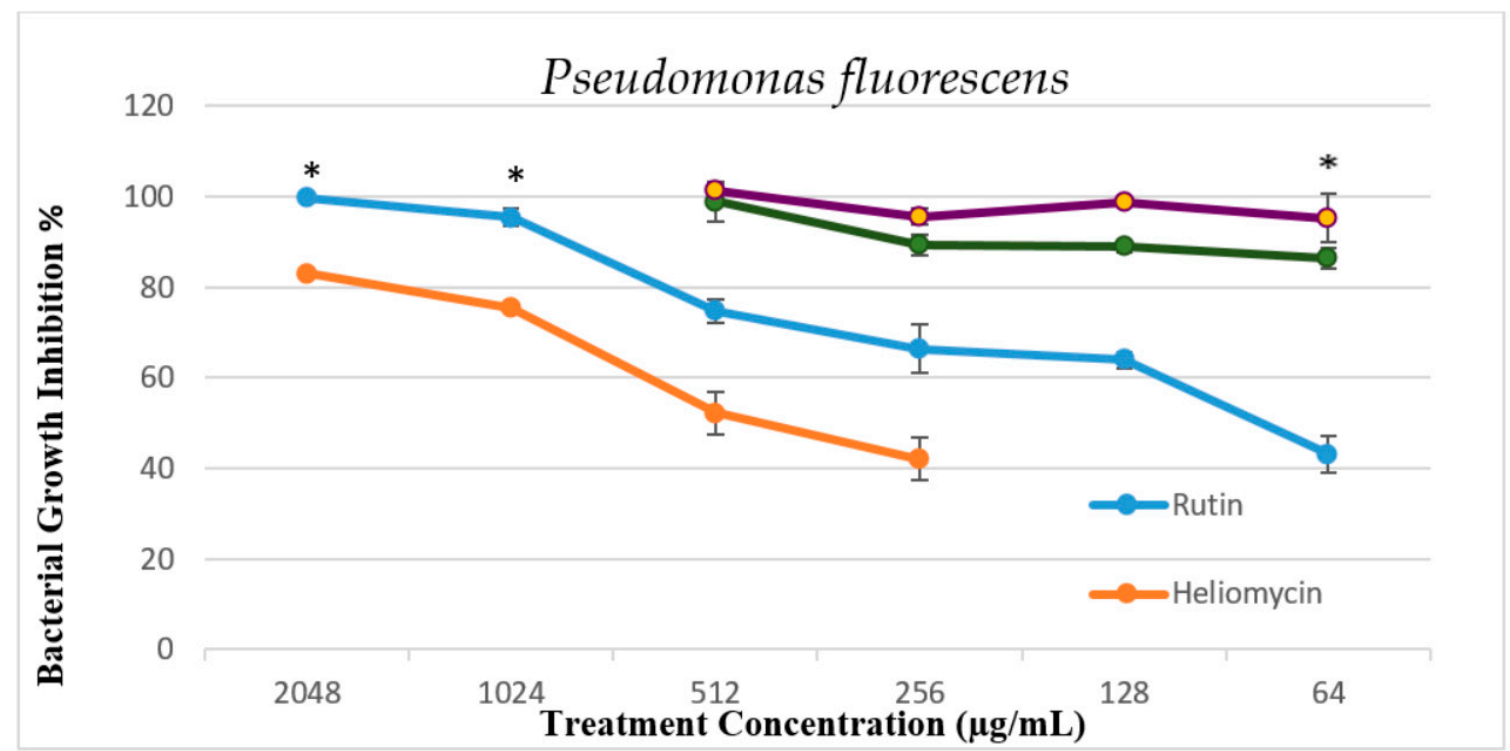

Figure 6. Percent inhibition of $P$. fluorescens growth when tested against serial dilutions of rutin and heliomycin $(2048 \mu \mathrm{g} / \mathrm{mL}$ to $64 \mu \mathrm{g} / \mathrm{mL}$ ) and sub-MIC combinations of AgNPs + rutin (R) and AgNPs + heliomycin (H). All data are expressed as means $\pm \mathrm{SD}(n=3)$. Error bars represent the standard deviation from average values. * Statistical significance from control $(p<0.05)$. 


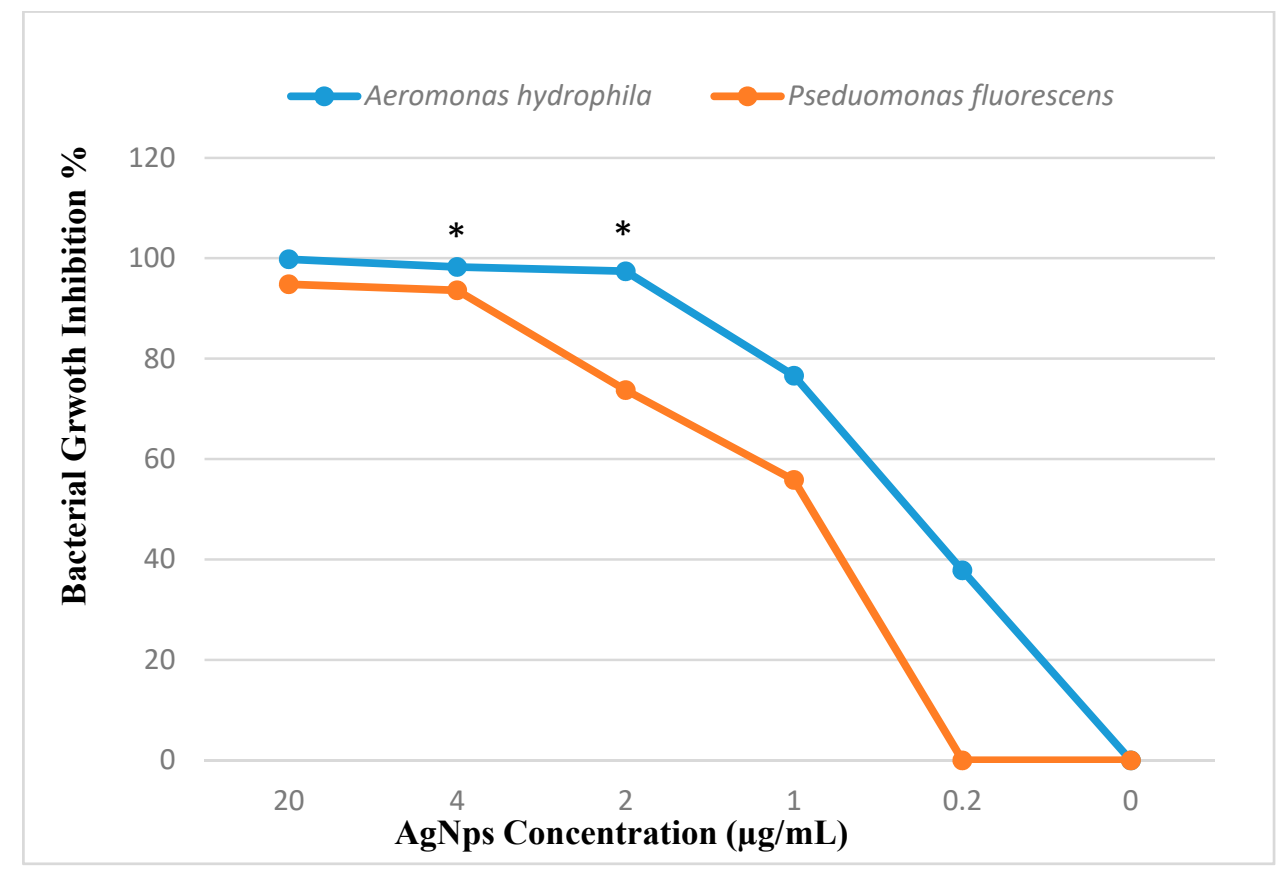

Figure 7. Percent inhibition of A. hydrophila and P. fluorescens at tested silver nanoparticles AgNPs doses $(0-20 \mu \mathrm{g} / \mathrm{mL})$. All data are expressed as means $\pm \operatorname{SD}(n=3) .{ }^{*}$ Statistical significance from control $(p<0.05)$.

\subsection{Cytotoxicity Assessment of Bioactive Compounds}

\subsubsection{Cell Morphology}

The morphology of EPC cells is one of the significant indicators of cell status. The morphological changes of EPC cells after $24 \mathrm{~h}$ exposure to the tested compounds were captured using an inverted microscope. Both the control cells and rutin-treated $(1024 \mu \mathrm{g} / \mathrm{mL})$ cells were large and elongated with good adherence (Figure 8a,b), indicating that the rutin treatment was safe. Most of the heliomycin-treated cells lost their adherence from the culture plate, became spherical and pyknotic, and started to float in the medium, finally leading to their death, indicating a highly cytotoxic effect of heliomycin (Figure 8c). A similar effect was observed to a lower extent for the combination of AgNPs + H (Figure 8f). The AgNPs-treated cells (Figure 8d) and sub-MIC of AgNPs in combination with rutin (Figure 8e) showed extended cytoplasm for intact cells and moderate morphological changes.

(a)

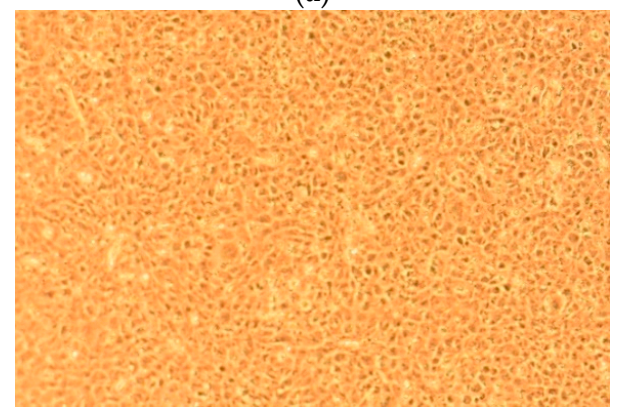

(d)

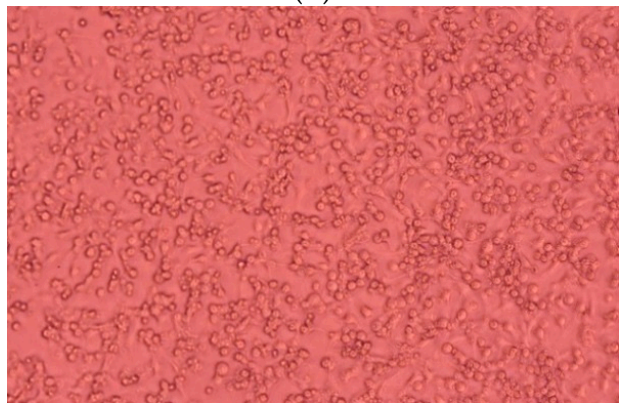

Figure 8. Cont. 
(b)

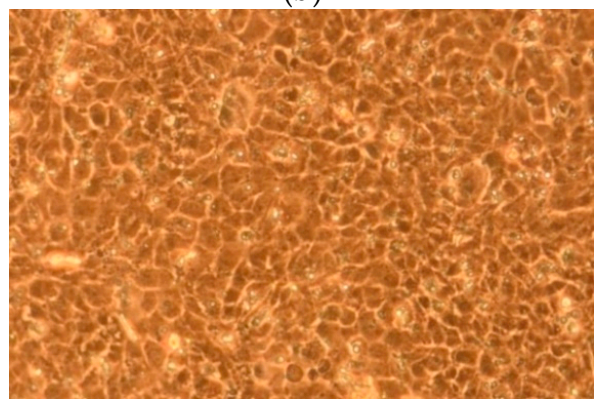

(c)

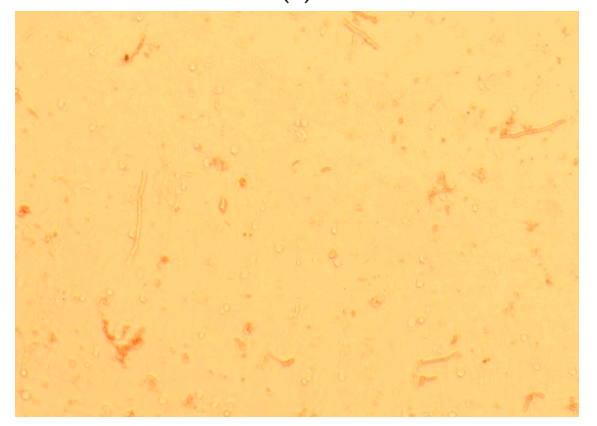

(e)

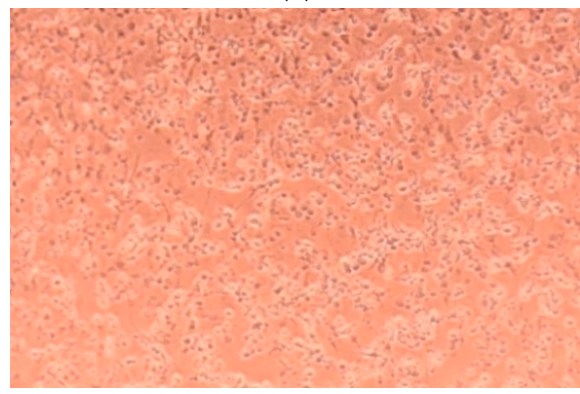

(f)

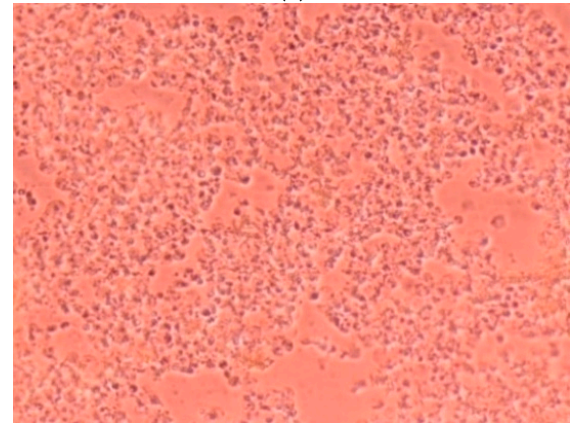

Figure 8. Morphological changes of epithelioma papulosum cyprinid (EPC) fish cell lines exposed to MIC of tested treatments for $24 \mathrm{~h}$. No morphological changes were observed in control cells (a) and in rutin-treated cells at $1024 \mu \mathrm{g} / \mathrm{mL}$, (b) while cell detachment, vacuolations, and cell swelling were observed in heliomycin-treated cells at $1024 \mu \mathrm{g} / \mathrm{mL}$ (c) and in combination with AgNPs (AgNPs $1 \mu \mathrm{g} / \mathrm{mL}+\mathrm{H} 64 \mu \mathrm{g} / \mathrm{mL}$ ). (f) A mild cell shrinkage was observed in AgNPs-treated cells with MIC $(2 \mu \mathrm{g} / \mathrm{mL})(\mathbf{d})$ and in combination with rutin-treated cells (AgNPs $1 \mu \mathrm{g} / \mathrm{mL})+\mathrm{R} 64 \mu \mathrm{g} / \mathrm{mL}(\mathbf{e})$.

\subsubsection{Cell Viability Results}

Alamar blue assay revealed a high viability of EPC cells $(97 \%)$ when treated with rutin MIC at $1024 \mu \mathrm{g} / \mathrm{mL}$ with dose-dependent cytotoxicity and with no significant difference $(p$ $>0.5$ ) when compared to the negative, untreated control cells. On the other hand, a dosedependent reduction in cell viability was observed after $24 \mathrm{~h}$ incubation with heliomycin. A combination of rutin and AgNPs showed high viability, while a subtherapeutic dose of AgNPs $+\mathrm{H}$ showed less cell viability (Figure 9a). AgNPs alone showed moderate viability of $65 \%$ at MIC and increased to $78 \%$ when subjected to ( $0.5 \mathrm{MIC})$ concentration of $(1 \mu \mathrm{g} / \mathrm{mL})$ (Figure $9 \mathrm{~b})$. All data are expressed as means \pm SD and are represented in a line chart (Figure 9). 


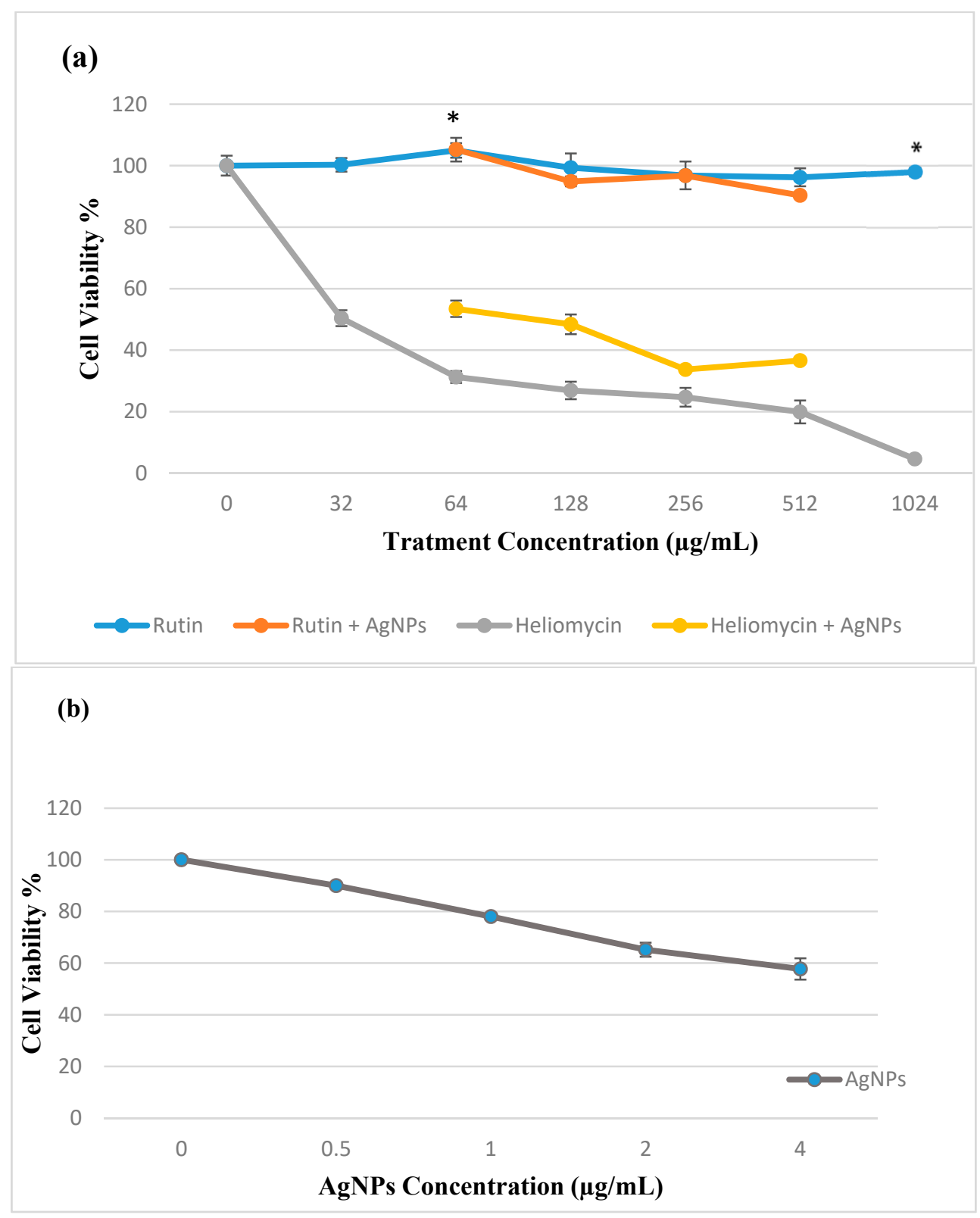

Figure 9. Assessment of in vitro cytotoxicity of tested bioactive compounds on the EPC cell line after 24 h exposure by Alamar blue assay. (a) Rutin and heliomycin two-fold serial dilutions sub-MIC combinations with AgNPs $(1 \mu \mathrm{g} / \mathrm{mL})$. (b) Cell viability against AgNPs serial dilution. * Statistical significance from control $(p<0.05)$.

\section{Discussion}

The utilization of silver nanoparticles in biomedicine opened doors to several opportunities but has also brought along considerable threats. Some drawbacks associated with AgNPs use have been reported such as treatment accumulation at nontargeted sites, immunogenic and fibrogenic potential, high reactivity, oxidative stress contributing properties, and longer persistence [26]. In addition to the ability to cross various barriers, AgNPs interact with different cellular components such as proteins, lipids, and genetic material [27]. Therefore, a balance between safety and efficacy is necessary for the development of novel nontherapeutic agents.

Bacterial infectious diseases are major threats to cultured fish. However, there is also an increasing need to minimize the use of antibiotics in farming to combat antibiotic resistance [28]. Hence, alternative antimicrobial therapeutics such as metal nanoparticles are widely investigated for their potential medical applications, including their use in 
fish medicine. Although metal nanoparticles such as AgNPs were reported to show efficient antimicrobial activity [26], limitations for their applications in therapeutic purposes still exist.

The present study examined the synergistic effect of biosynthesized AgNPs with bioactive natural products; from plant origin (rutin), and with a secondary metabolite of microbial origin (heliomycin) on fish pathogens. Improved safety and tolerability were observed by testing on fish cell lines. The green synthesis method was applied to synthesize AgNPs as a safe, eco-friendly, and efficient method that depends on the reduction power of EPS released by Bacillus nitratireducens, a soil isolate obtained from the rhizosphere of the wheat plant [29]. The biosynthesized AgNPs exhibited a potent bactericidal effect against $A$. hydrophila with an MBC of $2 \mu \mathrm{g} / \mathrm{mL}$ (Table 1), and an MIC of $2 \mu \mathrm{g} / \mathrm{mL}$, showing increased values than those previously reported by our group [11], while the MIC of AgNPs against $A$. hydrophila was $16 \mu \mathrm{g} / \mathrm{mL}$. This high potency of AgNPs could be explained due to their small size of approximately $12 \mathrm{~nm}$ and average sample size of $73 \mathrm{~nm}$, good $p(0.36)$, and a high zeta potential $(-33.8 \mathrm{mV})$. These results build on the existing evidence [30] in which biosynthesized AgNPs showed a size-dependent effect. Small nanoparticles can pass through pores in the cellular membrane, release a large number of silver ions, generate reactive oxygen species [31], and exhibit a high surface-area-to-volume ratio [32].

Rutin is one of the most abundant flavonoids found in plants. Reports indicate a variety of biological activities, such as analgesic, anti-inflammatory, antiarthritic, and antibacterial effects [33]. Rutin exhibited a dose-dependent response against both tested strains. The MIC values of rutin were observed at $1024 \mu \mathrm{g} / \mathrm{mL}$ against $A$. hydrophila and $P$. fluorscens, which indicate a moderate antibacterial effect. The antibacterial activities of rutin observed in this study were in line with a previous report [34] that reported an MIC of $1100 \mu \mathrm{g} / \mathrm{mL}$ against $A$. hydrophila. Orhan et al. [34] demonstrated rutin's efficacy against drug-resistant isolates such as Staphylococcus aureus and P. fluorescens aeruginosa using the broth microdilution method. In addition, the authors found that rutin isolated from tobacco leaves effectively inhibited fungal and bacterial growth. Heliomycin, another tested bioactive compound examined in the current study, is a secondary metabolite produced by actinomycetes AB5 isolated from soil sediment of the river Nile, Egypt [35]. It inhibits the synthesis of ATP and pyrophosphate by uncoupling the processes of respiration and oxidative phosphorylation, which affects the energy metabolism of bacterial cells. Moreover, it inhibits bacterial RNA synthesis [20]. To the best of our knowledge, the effect of heliomycin has not yet been completely studied against fish pathogens. In the present study, heliomycin showed a bacteriostatic effect against A. hydrophila and P. fluorescens with the MIC at $2048 \mu \mathrm{g} / \mathrm{mL}$, while the MBC could not be reached for the tested concentrations of the compound. These moderate antibacterial effects of both rutin and heliomycin could be due to their poor solubility in the aqueous phase $[33,36]$. The addition of biosynthesized AgNPs to rutin (AgNPs $+\mathrm{R})$ and heliomycin $(\mathrm{AgNPs}+\mathrm{H})$ improves their bioavailability for a couple of reasons: first, the electrostatic interaction between positive AgNPs and negative electron density on natural phenolic compounds, and second, the larger surface area of AgNPs increases the binding capacity to rutin and heliomycin molecules that potentiate their cellular uptake and hence their overall efficacy against infectious bacteria. This hypothesis is built on the existing evidence about the additive effect of AgNPs with phenolic plant extract [37] in which an AgNPs and curcumin combination gave a better antibacterial effect than the individual treatment. This hypothesis is in accordance with the study conducted by Barbinta-Patrascu et al., who developed hybrid bio-platforms based on a combination of AgNPs and natural compounds [38]. We first examined the enhanced effect of the AgNPs $+\mathrm{R}$ and AgNPs $+\mathrm{H}$ combination versus individual treatments against $P$. fluorescens using the disc diffusion method (Figure 4), and it resulted in a significant increase in the inhibition zone. These results support our hypothesis, and some reports are in agreement with earlier studies [29,39]. However, the disc diffusion method does not have a parameter to determine the synergistic effect. Therefore, we used the broth microdilution method to perform the synergy study and to identify the break point according to Clinical 
and Laboratory Standards Institute (CLSI) document VET01-A3 [26]. Data analysis showed an enhanced bactericidal effect of rutin in combination with AgNPs against $A$. hydrophila. This demonstrated an improved percent inhibition of bacterial growth from $40 \%$ individual sub-MIC of rutin at $64 \mu \mathrm{g} / \mathrm{mL}$ to approximately $100 \%$ combined sub-MIC of AgNPs treatment (Figure 5). The difference in susceptibility to the combined treatment effect of AgNPs + bioactive compound, to be additive or synergistic, depends on the ability of the nanosystem to penetrate the bacterial capsule that formed from the exopolysaccharide biofilm [40], which is still poorly understood due to its spatial and chemical variability and complexity. Hence, in-depth knowledge is required to the nature and composition of the biofilm matrix to properly design the nanosystem that is able to disrupt it [41].

The cytotoxicity of AgNPs, rutin, heliomycin, and their combinations were evaluated on the EPC cell line using Alamar blue assay [42,43]. Measuring the metabolic activity of the mitochondrial enzyme via quantification of its reducing power to convert the oxidized form of resazurin (blue color) to its reduced form (pink color) enables the comparison between the viability of the treated cells and untreated control cells. Low doses of heliomycin were tolerated, but the MIC dose of heliomycin $(1024 \mu \mathrm{g} / \mathrm{mL})$ was highly cytotoxic to EPC as well as its combinations at sub-MIC concentrations with AgNPs $(1 \mu \mathrm{g} / \mathrm{mL})$. These results agree with Abdelfattah et al. [24], in which the high cytotoxic effect of heliomycin against cancer cell lines via inhibiting histone deacetylase enzyme activity was reported. Low doses of AgNPs at MIC ( $2 \mu \mathrm{g} / \mathrm{mL})$ exhibited moderate morphological changes and tolerability and are in agreement with previous studies [44,45]. On the other hand, no significant cytotoxicity was observed with the rutin MIC dose (1024 $\mu \mathrm{g} / \mathrm{mL}, p>0.99)$, indicating the high safety of the rutin treatment. This could be explained by its reported antioxidant activities [46]. The viability of the EPC cell line was more than $90 \%$ without significant change in their morphology after the incubation with rutin MIC and in combination with AgNPs at sub MIC of $(1 \mu \mathrm{g} / \mathrm{mL})+\mathrm{R}(64 \mu \mathrm{g} / \mathrm{mL})$ and is in accordance with Barbinta-Patrascu et al. [38], in which the safety and efficacy of the combination of natural molecules with AgNPs were reported to support the synergistic and additive effects of these treatments and open a possibility for both biomedical and aquaculture applications.

\section{Material and Methods}

\subsection{Extraction and Characterization of Rutin}

The natural flavonoid rutin was extracted from the dried ground leaves of Ruta graveneoles, as previously described [47]. Briefly, the dried leaves (1000 g) were mixed with $70 \%$ ethanol at room temperature and then filtered, extraction was repeated five times, and was followed by evaporation under reduced pressure. The aqueous layer was collected and left to stand for three days. A yellow precipitate separated out of the solution. The precipitate was filtrated and washed three times with dichloromethane: ethyl acetate (2:1) to give $500 \mathrm{mg}$ of a yellow solid compound. Rutin was obtained from the library of the Natural Product Lab., Faculty of Science, Helwan University, Cairo, Egypt.

\subsection{Extraction and Characterization of Heliomycin}

Heliomycin was extracted from the culture broth of actinomycete AB5, as described previously [35]. In brief, the fermentation broth was harvested after four days and centrifuged at $4000 \mathrm{rpm}$ for $10 \mathrm{~min}$. The resulting mycelial cake was extracted three times with methanol, and the aqueous phase was extracted with ethyl acetate. A formed brown crude extract was dissolved in methanol and left to stand overnight. A yellow precipitate was split apart, filtrated, and washed three times with methanol to give a yellow solid compound. The structure of the extracted compound was characterized by spectroscopic methods such as nuclear magnetic resonance (NMR) and mass spectrometry. Heliomycin was obtained from the library of the Marine Natural Product Unit, Natural Product Lab., Faculty of Science, Helwan University, Cairo, Egypt. 


\subsection{Biosynthesis and Characterization of Silver Nanoparticles (AgNPs)}

$\mathrm{AgNPs}$ were synthesized by the reduction of $\mathrm{AgNO}_{3}$ using EPS released by Bacillus nitratireducens isolated from soil, according to Wenjie Jian et al. [35]. Characterization of particle size and zeta potential was performed based on dynamic light scattering (DLS) by using a Malvern Zetasizer Nano ZS device. This characterization analysis was performed in triplicate on diluted AgNPs suspension prepared in de-ionized distilled water. The DLS was measured at a $90^{\circ}$ scattering angle at $25^{\circ} \mathrm{C}$.

\subsection{Assessment of the Antibacterial Activities of AgNPs and Natural Phenolic Compounds}

\subsubsection{Bacterial Strains and Growth Conditions}

Aliquots of two fish pathogenic bacterial isolates A. hydrophila (252/13) and P. fluorescens were obtained from the Micro Bank in the Clinical Division of Fish Medicine, University of Veterinary Medicine, Vienna, Austria. Confirmatory identification was performed using MALDI-TOF (Bruker, Karlsruhe, Germany) and by analytical profile index (API). Both the bacterial isolates were confirmed using $16 \mathrm{~S}$ rRNA sequencing, as previously reported [13]. Then, under aseptic conditions, a loop from each pure strain was streaked on Müller-Hinton (MH) agar plates (Sigma-Aldrich, Vienna, Austria) and incubated at $22{ }^{\circ} \mathrm{C}$ for $24 \mathrm{~h}$.

\subsubsection{Bacterial Growth Inhibition Assay}

A single colony of each isolate was inoculated in $10 \mathrm{~mL}$ Müller-Hinton (MH) broth and incubated for $24 \mathrm{~h}$ in a shaker incubator at $126 \mathrm{rpm}$ at $22{ }^{\circ} \mathrm{C}$ [9]. The bacterial growth was monitored at optical density (OD) $600 \mathrm{~nm}$ using a spectrophotometer (Eppendorf BioPhotometer, Eppendorf, Hamburg, Germany) to get $10^{6}$ colony forming units (CFU $/ \mathrm{mL}$ ) cells. Equal volumes of each bacterial strain were mixed with tested compounds to reach a final concentration of $5 \times 10^{5} \mathrm{CFU} / \mathrm{mL}$. A negative control was prepared by mixing equal volumes of bacteria and $\mathrm{MH}$ media.

\subsubsection{Minimum Inhibitory Concentration (MIC) Assay}

The MIC assay for AgNPs, rutin, heliomycin, AgNPs $+\mathrm{R}$, and AgNPs $+\mathrm{H}$ against multiple drug-resistant strains of $A$. hydrophila and P. fluorescens was performed by the standard broth microdilution method according to the Clinical and Laboratory Standards Institute (CLSI) [48]. All experimental analyses were performed in triplicate. The bacterial growth was evaluated visually, and the MIC was determined as the lowest concentration that completely inhibited the growth.

Minimum Bactericidal Concentration (MBC) Assay:

To evaluate the MBC, $100 \mu \mathrm{L}$ was taken out from the wells without visible cell growth and incubated on agar plates, followed by incubation at $22{ }^{\circ} \mathrm{C}$ for $24 \mathrm{~h}$. After incubation, CFUs were counted and digital images of the plates were captured. The MBC was determined as the lowest concentration that inhibited colony formation. The assay was performed in triplicate, and the results, repeated twice or more, were considered [49].

\subsubsection{Synergy Study}

We examined different preparations of sub-MICs for AgNPs in combination with rutin $(\mathrm{AgNPs}+\mathrm{R})$ and heliomycin $(\mathrm{AgNPs}+\mathrm{H})$, as described before [34]. We selected rutin and heliomycin concentrations at $512 \mu \mathrm{g} / \mathrm{mL}$ (0.5 MIC), $256 \mu \mathrm{g} / \mathrm{mL}(0.25 \mathrm{MIC}), 128 \mu \mathrm{g} / \mathrm{mL}$ (0.125 MIC), and $64 \mu \mathrm{g} / \mathrm{mL}(0.062 \mathrm{MIC})$ that could be used synergistically with AgNPs sub-MIC of $1 \mu \mathrm{g} / \mathrm{mL}$ ( $0.5 \mathrm{MIC}$ ) (Table 2). The fractional inhibitory concentration index (FICI) values were calculated as follows: 
The FICI values for synergism, indifference, and antagonism were deduced as $\leq 0.5$, $>0.5$ to $\leq 4.0$, and $>4.0$, respectively.

\subsubsection{Disc Diffusion Method}

The possible synergistic/additive antimicrobial effects of AgNPs in combination with rutin $(\mathrm{AgNPs}+\mathrm{R})$ and heliomycin $(\mathrm{AgNPs}+\mathrm{H})$ against $P$. fluorescens was visualized and tested using the disc diffusion method, according to CLSI guidelines [50].

\subsubsection{UV-Visible Absorption}

To confirm the bacterial growth inhibition, the OD at $600 \mathrm{~nm}$ of the inoculated broth media of all the replicate test tubes corresponding to the sensitive isolates during the MIC assay was measured using a 96-well plate absorbance reader, Tecan Sunrise (Männdorf, Switzerland) [51]. The low absorbance capacity indicated less bacterial growth and vice versa. Blanks used for the OD measurements were the same as the MIC blank controls. The antibacterial effect of each dose for bioactive compounds was expressed as percentage inhibition (\%) of the bacterial growth according to the following equation [52]:

$$
\text { Inhibition }(\%)=1-\left(\frac{\text { OD sample }}{\text { OD control }}\right) \times 100
$$

The growth inhibition percent of each replicate was calculated from the obtained $\mathrm{OD}_{600}$ measurements, and the results were expressed as mean percentages \pm standard deviation (SD) in histograms comparing the species-specific antibacterial efficacy of the compound preparations.

\subsection{Cytotoxicity Assay}

\subsubsection{Fish Cell Lines and Culture Condition}

The fish cell line EPC, from carp (Cyprinus carpio), was cultivated on a 24-well tissue culture plate containing minimal essential medium (MEM, Gibco ${ }^{\circledR}$, New York, NY, USA), supplemented with $2 \%$ fetal bovine serum. EPC cells were incubated at $20{ }^{\circ} \mathrm{C}$ for $24 \mathrm{~h}$ until a confluent monolayer and an approximate cell seeding density of $2 \times 10^{5}$ was achieved.

\subsubsection{Cell Morphology Examination}

The culture medium was replaced with fresh medium containing selected treatment concentrations of bioactive compounds according to the MIC data given in Tables 1 and 2. After incubation at $19{ }^{\circ} \mathrm{C}$ for $24 \mathrm{~h}$, EPC cells morphology was recorded using an inverted phase-contrast microscope (Nikon, Tokyo, Japan) at $20 \times$ magnification.

\subsubsection{Cytotoxicity and Cell Viability Assessment}

In vitro safety assessment of bioactive compounds was performed [53] as follows. Briefly, $200 \mu \mathrm{L}$ MEM containing approximately $4 \times 10^{4}$ EPC cells was seeded into each well of 96-well plates and allowed to adhere at a temperature of $19{ }^{\circ} \mathrm{C}$. After the formation of the confluent monolayer, all media were replaced with the new media containing a two-fold serial dilution of the bioactive compounds rutin $(0-1024 \mu \mathrm{g} / \mathrm{mL})$, heliomycin $(0-1024 \mu \mathrm{g} / \mathrm{mL})$, AgNPs $(0-4 \mu \mathrm{g} / \mathrm{mL})$, and sub-MIC combinations of AgNPs $+\mathrm{R}$ and AgNPs + H (Table 2). The negative control, growth control, and media blank were included, and then the plate was incubated for $24 \mathrm{~h}$ at $19{ }^{\circ} \mathrm{C}$. The medium was then removed, and the wells were washed with phosphate buffer saline (PBS) twice to remove any residual particles. The viability of EPC cells was tested using an Alamar blue high-sensitivity assay (Invitrogen ${ }^{\circledR}$, Oregon, OR, USA) according to the manufacturer's instructions [54,55]. After $3 \mathrm{~h}$ incubation, the wells were read using a spectrophotometric plate reader, Tecan Sunrise (Männdorf, Switzerland), at respective oxidized and reduced forms at wavelengths of 550 $\mathrm{nm}$ and $600 \mathrm{~nm}$. The percentage of surviving cells was calculated for each well, and the survival percent (viability) was expressed as mean percent \pm SD. The assay was performed in triplicate for each treatment and single control well per assay. 


\subsection{Statistical Analysis}

All data were expressed as means \pm SD obtained from $\geq 3$ independent experiments performed on different days with at least one replicate per experiment. The obtained data were checked using Levene's test. The statistical analysis was performed using SPSS 25 (IBM) software for the covariance (ANOVA) [56] with post hoc Dunnett's T3 test for paired comparison of the means. The statistical significance of differences from control values was taken at $p<0.05$, evaluating the data at a $>95 \%$ confidence level. All $p$-values of $<0.01$ and $<0.001$ were considered significant and highly significant, respectively.

\section{Conclusions}

Biosynthesized AgNPs, rutin, and heliomycin demonstrated in vitro dose-dependent antimicrobial efficacy against $A$. hydrophila and P. fluorescens. The enhanced effect of rutin and heliomycin was achieved by a combination of their subtherapeutic doses with AgNPs, wherein AgNPs could improve their solubility and hence potency. In terms of safety among the tested compounds when tested on EPC cells, rutin exhibited high tolerability, followed by the sub-MIC combination of (AgNPs + rutin). Hence, rutin as a natural flavonoid compound is an effective and safe antibacterial agent and could be used in combination with AgNPs for disease management in aquaculture. Further in vivo studies are required to investigate the antimicrobial efficacy and safety of these combinations on living fish.

Author Contributions: E.E., M.S., and M.E.-M. conceptualized and designed the study. M.S. and M.E.-M. supervised the study. E.E. wrote and M.S. revised the manuscript draft. M.S.A. provided bioactive compounds. E.E. and M.S.A. performed practical experiments. E.E. conducted data analysis. M.S. and M.E.-M. reviewed the manuscript. All authors have read and agreed to the published version of the manuscript.

Funding: This study was funded in part by the University of Veterinary Medicine, Vienna, Austria, and by the Austrian Science Fund (FWF) Project No. P 32340-B to Mona Saleh.

Institutional Review Board Statement: Not applicable.

Informed Consent Statement: Not applicable.

Acknowledgments: We would like to thank the missions' sector in the ministry of higher education and scientific research, Egypt, for supporting the postdoctoral scholarship to Ehab Essawy. The authors would like to appreciate Simon Menanteau-Ledouble, Hatem Soliman, and Oskar Schahnar (University of Veterinary Medicine, Vienna, Austria) for their kind help. Additionally, we thank Ahmed Farag, Microbiology Department, Faculty of Science, Helwan University, for help in AgNPs characterization. Open Access Funding by the Austrian Science Fund (FWF).

Conflicts of Interest: The authors declare that they have no competing interest.

\section{References}

1. Suez, O. Bacteria associated with fresh-water aquaculture tilapia fish (Oreochromis niloticus) in Suez, Egypt. Food Sci. Nutr. Res. 2019, 2, 1-7.

2. Karunasagar, I. Zoonoses_-Infections Affecting Humans and Animals; Springer: Dordrecht, The Netherlands, 2015.

3. Menanteau-Ledouble, S.; Lawrence, M.L.; El-Matbouli, M. Invasion and replication of Yersinia ruckeri in fish cell cultures. BMC Vet. Res. 2018, 14, 1-11. [CrossRef] [PubMed]

4. Brown, P.; Dawson, M.J. A perspective on the next generation of antibacterial agents derived by manipulation of natural products. In Progress in Medicinal Chemistry; Elsevier B.V.: Oxford, UK, 2015; Volume 54, pp. 135-184.

5. Stratev, D.; Odeyemi, O.A. Antimicrobial resistance of Aeromonas hydrophila isolated from different food sources: A mini-review. J. Infect. Public Health 2016, 9, 535-544. [CrossRef] [PubMed]

6. Sellegounder, D.; Gupta, Y.R.; Murugananthkumar, R.; Senthilkumaran, B. Enterotoxic effects of Aeromonas hydrophila infection in the catfish, Clarias gariepinus: Biochemical, histological and proteome analyses. Vet. Immunol. Immunopathol. 2018, 204, 1-10. [CrossRef] [PubMed]

7. Zhou, Z.J.; Zhang, L.; Sun, L. Pseudomonas fluorescens: Fur is required for multiple biological properties associated with pathogenesis. Vet. Microbiol. 2015, 175, 145-149. [CrossRef] [PubMed]

8. Samayanpaulraj, V.; Velu, V.; Uthandakalaipandiyan, R. Determination of lethal dose of Aeromonas hydrophila Ah17 strain in snake head fish Channa striata. Microb. Pathog. 2019, 127, 7-11. [CrossRef] 
9. Shaalan, M.I.; El-Mahdy, M.M.; Theiner, S.; El-Matbouli, M.; Saleh, M. In vitro assessment of the antimicrobial activity of silver and zinc oxide nanoparticles against fish pathogens. Acta Vet. Scand. 2017, 59. [CrossRef]

10. Saleh, M.; Kumar, G.; Abdel-Baki, A.A.; Al-Quraishy, S.; El-Matbouli, M. In vitro antimicrosporidial activity of gold nanoparticles against Heterosporis saurida. BMC Vet. Res. 2016, 12, 1-6. [CrossRef]

11. Shaalan, M.; El-Mahdy, M.; Theiner, S.; Dinhopl, N.; El-Matbouli, M.; Saleh, M. Silver nanoparticles: Their role as antibacterial agent against Aeromonas salmonicida subsp. salmonicida in rainbow trout (Oncorhynchus mykiss). Res. Vet. Sci. 2018, 119, 196-204. [CrossRef]

12. Saleh, M.; Abdel-Baki, A.A.; Dkhil, M.A.; El-Matbouli, M.; Al-Quraishy, S. Antiprotozoal effects of metal nanoparticles against Ichthyophthirius multifiliis. Parasitology 2017, 114, 1802-1810. [CrossRef]

13. Ahmed, F.; Soliman, F.M.; Adly, M.A.; Soliman, H.A.M.; El-Matbouli, M.; Saleh, M. In vitro assessment of the antimicrobial efficacy of chitosan nanoparticles against major fish pathogens and their cytotoxicity to fish cell lines. J. Fish Dis. 2020. [CrossRef]

14. Mao, B.H.; Chen, Z.Y.; Wang, Y.J.; Yan, S.J. Silver nanoparticles have lethal and sublethal adverse effects on development and longevity by inducing ROS-mediated stress responses. Sci. Rep. 2018, 8, 1-16. [CrossRef]

15. Rajkumar, K.S.; Kanipandian, N.; Thirumurugan, R. Toxicity assessment on haemotology, biochemical and histopathological alterations of silver nanoparticles-exposed freshwater fish Labeo rohita. Appl. Nanosci. 2016, 6, 19-29. [CrossRef]

16. Shati, A.A.; Elsaid, F.G. Biosynthesized silver nanoparticles and their genotoxicity. J. Biochem. Mol. Toxicol. 2020, 34, 1-7. [CrossRef]

17. Orhan, D.D.; Özçelik, B.; Özgen, S.; Ergun, F. Antibacterial, antifungal, and antiviral activities of some flavonoids. Microbiol. Res. 2010, 165, 496-504. [CrossRef]

18. Enogieru, A.B.; Haylett, W.; Hiss, D.C.; Bardien, S.; Ekpo, O.E. Rutin as a potent antioxidant: Implications for neurodegenerative disorders. Oxid. Med. Cell. Longev. 2018, 27,1-17. [CrossRef]

19. Gautam, R.; Singh, M.; Gautam, S.; Rawat, J.K.; Saraf, S.A.; Kaithwas, G. Rutin attenuates intestinal toxicity induced by Methotrexate linked with anti-oxidative and anti-inflammatory effects. BMC Complement. Altern. Med. 2016, 16, 1-6. [CrossRef]

20. Arora, S.K. Molecular structure of heliomycin, an inhibitor of RNA synthesis. J. Antibiot. 1985, 38, 113-115. [CrossRef]

21. Fernandes, M.R.V.; Dias, A.L.T.; Carvalho, R.R.; Souza, C.R.F.; Oliveira, W.P. Antioxidant and antimicrobial activities of Psidium guajava L. spray dried extracts. Ind. Crop. Prod. 2014, 60, 39-44. [CrossRef]

22. Vijayabharathi, R.; Bruheim, P.; Andreassen, T.; Raja, D.S.; Devi, P.B.; Sathyabama, S.; Priyadarisini, V.B. Assessment of resistomycin, as an anticancer compound isolated and characterized from Streptomyces aurantiacus AAA5. J. Microbiol. 2011, 49, 920-926. [CrossRef]

23. Kock, I.; Maskey, R.P.; Biabani, M.A.F.; Helmke, E.; Laatsch, H. 1-Hydroxy-1-norresistomycin and resistoflavin methyl ether: New antibiotics from marine-derived streptomycetes. J. Antibiot. 2005, 58, 530-534. [CrossRef] [PubMed]

24. Abdelfattah, M.S.; Elmallah, M.I.Y.; Faraag, A.H.I.; Hebishy, A.M.S.; Ali, N.H. Heliomycin and tetracinomycin D: Anthraquinone derivatives with histone deacetylase inhibitory activity from marine sponge-associated Streptomyces sp. SP9. 3 Biotech. 2018, 8 [CrossRef] [PubMed]

25. Gołaś, I.; Szmyt, M.; Potorski, J.; Łopata, M.; Gotkowska-Płachta, A.; Glińska-Lewczuk, K. Distribution of pseudomonas fluorescens and aeromonas hydrophila bacteria in a recirculating aquaculture system during farming of European grayling (Thymallus thymallus L.) broodstock. Water 2019, 11, 376. [CrossRef]

26. Abdel-Tawwab, M.; Razek, N.A.; Abdel-Rahman, A.M. Immunostimulatory effect of dietary chitosan nanoparticles on the performance of Nile tilapia, Oreochromis niloticus (L.). Fish. Shellfish Immunol. 2019, 88, 254-258. [CrossRef] [PubMed]

27. Carew, A.C.; Hoque, M.E.; Metcalfe, C.D.; Peyrot, C.; Wilkinson, K.J.; Helbing, C.C. Chronic sublethal exposure to silver nanoparticles disrupts thyroid hormone signaling during Xenopus laevis metamorphosis. Aquat. Toxicol. 2015, 159, 99-108. [CrossRef]

28. Cabello, F.C.; Godfrey, H.P.; Tomova, A.; Ivanova, L.; Dölz, H.; Millanao, A.; Buschmann, A.H. Antimicrobial use in aquaculture re-examined: Its relevance to antimicrobial resistance and to animal and human health. Environ. Microbiol. 2013, 15, 1917-1942. [CrossRef]

29. Ghosh, S.; Patil, S.; Ahire, M.; Kitture, R.; Kale, S.; Pardesi, K.; Cameotra, S.; Bellare, J.; Dhavale, D.D.; Jabgunde, A.; et al. Synthesis of silver nanoparticles using Dioscorea bulbifera tuber extract and evaluation of its synergistic potential in combination with antimicrobial agents. Int. J. Nanomed. 2012, 7, 483-496.

30. Mahanty, A.; Mishra, S.; Bosu, R.; Maurya, U.K.; Netam, S.P.; Sarkar, B. Phytoextracts-synthesized silver nanoparticles inhibit bacterial fish pathogen Aeromonas hydrophila. Indian J. Microbiol. 2013, 53, 438-446. [CrossRef]

31. Carlson, C.; Hussein, S.M.; Schrand, A.M.; Braydich-Stolle, L.K.; Hess, K.L.; Jones, R.L.; Schlager, J.J. Unique cellular interaction of silver nanoparticles: Size-dependent generation of reactive oxygen species. J. Phys. Chem. B 2008, 112, 13608-13619. [CrossRef]

32. Rao, C.; Kulkarni, G.U.; Thomas, P.J.; Edwards, P.P. Size-dependent chemistry: Properties of nanocrystals. Chem. Eur. J. 2002, 8, 28-35. [CrossRef]

33. Ganeshpurkar, A.; Saluja, A.K. The Pharmacological Potential of Rutin. Saudi Pharm. J. 2017, 25, 149-164. [CrossRef] [PubMed]

34. Deepika, M.S.; Thangam, R.; Vijayakumar, T.S.; Sasirekha, R.; Vimala, R.T.V.; Sivasubramanian, S.; Arun, S.; Babu, M.D.; Thirumurugan, R. Antibacterial synergy between rutin and florfenicol enhances therapeutic spectrum against drug resistant Aeromonas hydrophila. Microb. Pathog. 2019, 135. [CrossRef] [PubMed] 
35. Mahmoud, A.A.; Essawy, E.A.; Abdalla, M.S.; Abdelfattah, M.S. Production of heliomycin from Actinomycete and evaluation of its antimicrobial activities. J. Biosci. Appl. Res. 2019, 5, 429-437. [CrossRef]

36. Nadysev, G.Y.; Tikhomirov, A.S.; Dezhenkova, L.G.; Shchekotikhin, A.E. Semi-synthetic derivatives of heliomycin with an antiproliferative potency. Recent Pat. Anticancer Drug Discov. 2018, 13, 469-472. [CrossRef] [PubMed]

37. Loo, C.Y.; Rohanizadeh, R.; Young, P.M.; Traini, D.; Cavaliere, R.; Whitchurch, C.B.; Lee, W.H. Combination of silver nanoparticles and curcumin nanoparticles for enhanced anti-biofilm activities. J. Agric. Food Chem. 2016, 64, 2513-2522. [CrossRef]

38. Barbinta-Patrascu, M.E.; Badea, N.; Pirvu, C.; Bacalum, M.; Ungureanu, C.; Nadejde, P.L.; Ion, C.; Rau, I. Multifunctional soft hybrid bio-platforms based on nano-silver and natural compounds. Mater. Sci. Eng. C 2016, 69, 922-932. [CrossRef] [PubMed]

39. Fayaz, A.M.; Balaji, K.; Girilal, M.; Yadav, R.; Kalaichelvan, P.T.; Venketesan, R. Biogenic synthesis of silver nanoparticles and their synergistic effect with antibiotics: A study against gram-positive and gram-negative bacteria. Nanomed. Nanotechnol. Biol. Med. 2010, 6, 103-109. [CrossRef]

40. Boyd, C.D.; Smith, T.J.; El-kirat-chatel, S.; Newell, P.D. Structural features of the Pseudomonas fluorescens biofilm adhesin LapA required for LapG-dependent cleavage, biofilm formation, and cell surface localization. J. Bacteriol. 2014, 196, $2775-2788$. [CrossRef]

41. Li, X.; Yeh, Y.C.; Giri, K.; Mout, R.; Landis, R.F.; Prakash, Y.S.; Rotello, V.M. Control of nanoparticle penetration into biofilms through surface design. Chem. Commun. 2015, 51, 282-285. [CrossRef]

42. Önlü, S.; Saçan, M.T. An in silico approach to cytotoxicity of pharmaceuticals and personal care products on the rainbow trout liver cell line RTL-W1. Environ. Toxicol. Chem. 2017, 36, 1162-1169. [CrossRef]

43. Nambi, K.S.N.; Majeed, S.A.; Taju, G.; Sivasubbu, S.; Babu, V.S.; Hameed, A.S.S. Effects of nicotine on zebrafish: A comparative response between a newly established gill cell line and whole gills. Comp. Biochem. Physiol. Part. C Toxicol. Pharmacol. 2017, 195, 68-77. [CrossRef]

44. El Mahdy, M.M.; Eldin, T.A.S.; Aly, H.S.; Mohammed, F.F.; Shaalan, M.I. Evaluation of hepatotoxic and genotoxic potential of silver nanoparticles in albino rats. Exp. Toxicol. Pathol. 2015, 67, 21-29. [CrossRef]

45. Farouk, M.M.; El-Molla, A.; Salib, F.A.; Soliman, Y.A.; Shaalan, M. The role of silver nanoparticles in a treatment approach for multidrug-resistant salmonella species isolates. Int. J. Nanomed. 2020, 15, 6993-7011. [CrossRef]

46. Yang, J.; Guo, J.; Yuan, J. In vitro antioxidant properties of rutin. LWT Food Sci. Technol. 2008, 41, 1060-1066. [CrossRef]

47. Abdelfattah, M.S.; Badr, S.E.A.; Lotfy, S.A.; Attia, G.H.; Aref, A.M.; Moneim, A.E.A.; Kassab, R.B. Rutin and selenium coadministration reverse 3-Nitropropionic acid-induced neurochemical and molecular impairments in a mouse model of huntington's disease. Neurotox. Res. 2020, 37, 77-92. [CrossRef]

48. Humphries, R.M.; Abbott, A.N.; Hindler, J.A. Understanding and addressing CLSI breakpoint revisions: A primer for clinical laboratories. J. Clin. Microbiol. 2019, 57. [CrossRef]

49. Du, W.L.; Niu, S.S.; Xu, Y.L.; Xu, Z.R.; Fan, C.L. Antibacterial activity of chitosan tripolyphosphate nanoparticles loaded with various metal ions. Carbohydr. Polym. 2009, 75, 385-389. [CrossRef]

50. Humphries, R.M.; Ambler, J.; Mitchell, S.L.; Castanheira, M.; Dingle, T.; Hindler, J.A.; Koeth, L.; Sei, K. CLSI methods development and standardization working group best practices for evaluation of antimicrobial susceptibility tests. J. Clin. Microbiol. 2018, 56, e01934-17. [CrossRef]

51. Ali, S.W.; Rajendran, S.; Joshi, M. Synthesis and characterization of chitosan and silver loaded chitosan nanoparticles for bioactive polyester. Carbohydr. Polym. 2011, 83, 438-446. [CrossRef]

52. Divya, K.; Vijayan, S.; George, T.K.; Jisha, M.S. Antimicrobial properties of chitosan nanoparticles: Mode of action and factors affecting activity. Fibers Polym. 2017, 18, 221-230. [CrossRef]

53. Taju, G.; Majeed, S.A.; Nambi, K.S.N.; Hameed, A.S.S. Application of fish cell lines for evaluating the chromium induced cytotoxicity, genotoxicity and oxidative stress. Chemosphere 2017, 184, 1-12. [CrossRef]

54. Thermofisher. Available online: https://assets.thermofisher.com/TFS-Assets/LSG/manuals/MAN0018369-alamarBlueHSCellViabilityReagent-PI.pdf (accessed on 7 January 2021).

55. Rampersad, S.N. Multiple applications of alamar blue as an indicator of metabolic function and cellular health in cell viability bioassays. Sensors 2012, 12, 12347-12360. [CrossRef] [PubMed]

56. Dytham, C. Choosing and Using Statístícs: A Biologist's Guide, 3rd ed.; Wiley-Blackwell: Hoboken, NJ, USA, 2011; ISBN 9781405198387. 